\title{
Idea of the ecological and geological tourist centre in Starunia (Fore-Carpathian region, Ukraine)
}

Ekologiczne i geologiczne centrum turystyczne w Staruni (Przedgórze Karpat, Ukraina)

\author{
Oleg M. Adamenko, Orest R. Stelmakh, Denis O. Zorin \& Katya O. Radlovska \\ Ivano-Frankivsk National Technical University of Oil and Gas, 15 Karpatska Street, \\ 76019 Ivano-Frankivsk, Ukraine, e-mail: stelmakh@ifdtung.if.ua
}
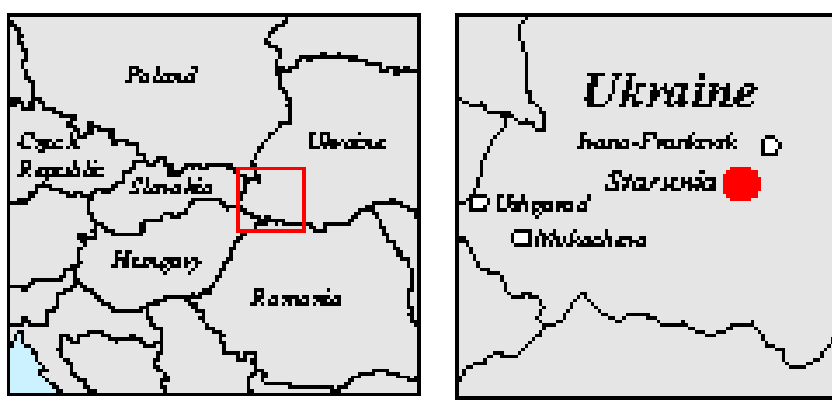

Abstract: In Starunia village ozokerite deposit was mined in the years 1868-1960. In 1907 remnants of woolly rhinoceros and mammoth were discovered in one of the shafts. A second discovery was made in 1929, in a special shaft digged by the Polish Academy of Arts and Sciences, where remnants of three woolly rhinoceroses were found including one, a unique in the world, almost completely preserved specimen of this extinct species. In the 1970s, mud volcanoes were formed in relationship to seismic activity. In the vicinity of Starunia Paleolithic settlements were found of human population which might have inhabitated this area in the same period as large mammals. Geological, palaeontological and archaeological factors along with beautiful landscape of the Ukrainian Carpathian region make the Starunia village exceptional, world-class geotourist attraction. Hence, the concept of ecological and geological tourist centre has been proposed, located at the abandoned ozokerite mine in Starunia village.

Key words: Starunia, ecological and geological-tourist centre, abandoned ozokerite mine, palaeontological site, Fore-Carpathian region, Ukraine

Treść: We wsi Starunia złoże ozokerytu byto eksploatowane w latach 1868-1960. W roku 1907 w jednym z szybów kopalni odkryto szczatki nosorożca wlochatego i mamuta. W roku 1929 w specjalnie wykopanym szybie przez Polska Akademię Umiejętności znaleziono jeszcze trzy szczatki nosorożców włochatych, $w$ tym jeden okaz prawie kompletnie zachowany unikatowy w skali światowej przedstawiciel tego wymartego gatunku. Ponadto w Staruni w latach 70-tych XX wieku utworzyty się wulkany błotne zwiazane $z$ aktywnościa sejsmiczna. W pobliżu Staruni znaleziono również szczatki osad paleolitycznych, zwiqzane z ludźmi, którzy mogli zamieszkiwać ten teren równocześnie z olbrzymimi ssakami. Walory geologiczne, paleozoologiczne i archeologiczne, a także położenie w pięknym krajobrazie Przedkarpacia Ukrainy, spowodowaty, ze wieś Starunia stała się wyjatkowq w skali światowej atrakcja geoturystycznq. W artykule przedstawiono plan utworzenia ekologicznego i geologicznego centrum turystycznego zlokalizowanego na obszarze nieczynnej kopalni ozokerytu w Staruni.

Stowa kluczowe: Starunia, centrum ekologiczne i geologicznoturystyczne, nieczynna kopalnia ozokerytu, stanowisko paleontologiczne, Przedgórze Karpat, Ukraina
Резюме: Родовище озокериту в с. Старуня розроблялося протягом 1868-1960 років. В 1907 роиі в одній з шахт було виявлено залишки волохатого носорога $і$ мамонта. В 1929 роиі Польською Академію Вміння була спеціально викопана штольня, в якій знову було знайдено ще трьох волохатих носорогів. Серед них один був надзвичайно добре збережений та унікальний в світовому масштабі представник иього вимерлого типу. Крім иього, в Старуні в 70-х роках XX сторіччя виникли болотні вулкани, пов'язані з сейсмічною активністю. В околииях Старуні знайдено також залишки палеолітичних поселень, пов'язані з людьми, які могли жити на цій території одночасно з величезними тваринами. Геологічні, палеозоологічні і археологічні умови, а також місиеположення серед прекрасних ландшафтів Прикарпаття Украӥни сприяють тому, щуо с. Старуня стало винятковим геотуристичним об'єктом світового масштабу. В статті представлено план створення екологічного і геологічного туристичного иентру, розміщеного на території відрацьованого озокеритового промислу в Старуні. Основні терміни: Старуня, екологічний і геологічний туристичний центр, відпрацьований озокеритовий промисел, палеолітичне поселення, передгір'я Карпат, Украӥна.

\section{Introduction}

Starunia is a beautiful village in the Carpathian region, in Bogorodchany sub-district, Ivano-Frankivsk (formerly Stanisławów, Stanislav) district, where economic-grade accumulations of ozokerite (earth wax) and oil coexist together with mud volcanoes and oil seeps. The relatively small, national protected area covers some 60 hectares (Fig. 1).

In Starunia village ozokerite deposit was mined in the years 1868-1960 (Alexandrowicz, 2004, 2005). In the 20th and the 19th centuries, in the vicinity of Starunia intensive drillings for oil and gas were carried on (Adamenko et al., 2005a). However, Starunia has been famous since 1907 as the site where remains of a woolly rhinoceros and a mammoth were found at depths of 12.5 and $17.6 \mathrm{~m}$, respectively below surface at the site where ozokerite was mined. This exceptional discovery was followed by next one, in 1929 when almost completely preserved carcass of woolly rhinoceros was excavated in the special shaft dug by the Polish Academy of Arts and Sciences. Additionally, bones of two woolly rhinoceroses were discovered in this shaft. Large, extinct mammals were buried between 40,000 and 35,000 years ago (Kuc et al., 2005; Kuc et al., 2011) within Pleistocene muds saturated by oil and brines. In the years following the first and the second discoveries specialists from Poland and Ukraine studied the fossils, now exhibited in museums 


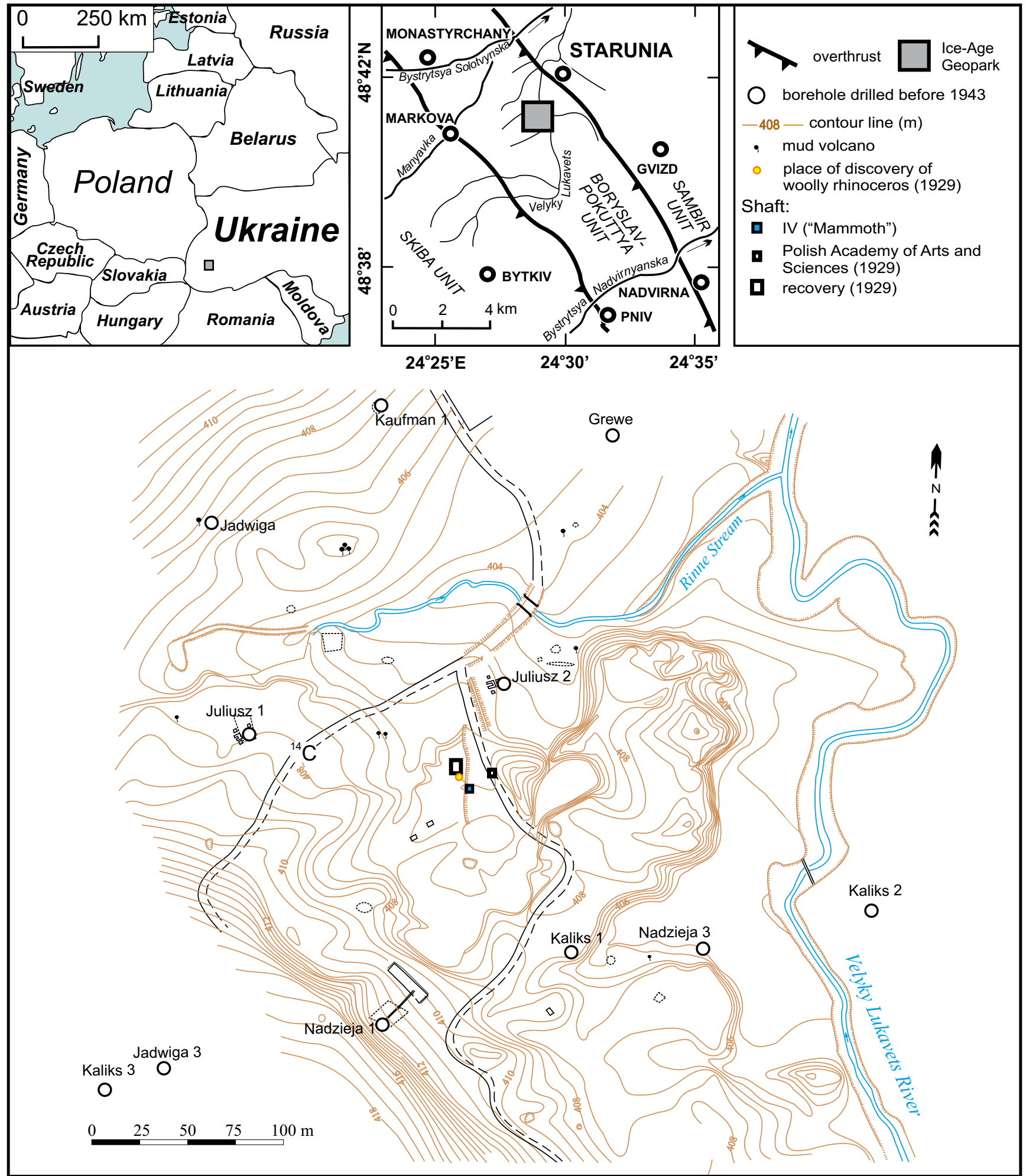

Fig. 1. Sketch map of the abandoned Starunia ozokerite mine (Fore-Carpathian region, Ukraine) • Mapa poglądowa nieczynnej kopalni ozokerytu w Staruni (Przedgórze Karpat, Ukraina)

in Kraków, Poland and in Lviv, Ukraine (Kubiak, 2009; Kubiak \& Drygant, 2009; Chornobay \& Drygant, 2009).

An extended overview of the Starunia site and discoveries was published by e.g., Bayger et al. (1914), Nowak et al. (1930) and recently by Professor S. W. Alexandrowicz in a monograph published in Polish (Alexandrowicz, 2004). This book was translated into Ukrainian and edited in 2008 by J. Gladuyn from the Ivano-Frankivsk National Technical Univers- ity of Oil and Gas in Ivano-Frankivsk and V. Kuylish - scientific worker of the Precarpathian National University in Ivano-Frankivsk.

Subsequently, extended, international, multidisciplinary research projects have been initiated by Professor M. J. Kotarba from the AGH University of Science and Technology in Kraków, Poland, in the years 2004-2005 (Kotarba, ed., 2005) and 2006-2009 (Kotarba, ed., 2009). 
The separate problem of mud volcanoes was studied in the years $1977-1987$ by V. Klyarovskiy and N. Belous from the Ivano-Frankivsk Institute of Oil and Gas in Ivano-Frankivsk. Mud volcano has appeared near Starunia village, on the eastern bank of the Great Lukavets River (Fig. 1) after an earthquake in the Vrancha Mts. (Romania) on March 4th, 1977. Following the proposal of Belous et al. (1985) and Belous \& Klyarovskiy (1987), Starunia was approved by the authorities as a Ukrainian National Geological Monument.

The unique character of the site gave rise to the proposal of an organization of international ecological and geological tourist centre named "The Park of the Ice Age" (Adamenko et al., 2005b). In future this park should be included on the list of the world network of geoparks (WGN) (www.worldgeopark.com). This idea has quickly spreaded via the internet and many people have started to explore the concept without the references to its father, Professor O.M. Adamenko. Therefore, the abandoned Starunia ozokerite mine is an important element of the planned Starunia (Ukraine) - Kraków (Poland) cross-border geotouristic route "Traces of large extinct mammals, earth wax, oil and salt" (Kotarba, 2009).

\section{Starunia - palaeontological and geological attraction}

The Starunia nature monument is situated on the eastern bank of the Velyky Lukavets River valley (Fig. 1), where a lot of outcrops and two river terraces occur at elevations 1 and $2.5 \mathrm{~m}$ above the river bed (Stelmakh, 2005).

Beneath the soil horizon a layer of yellowish-grey clay-sand mixture, about $0.5 \mathrm{~m}$ thick, was found at depth of $10-15 \mathrm{~cm}$ below surface. This rock contains thin intercalations of oxidized bitumen. In the vicinity archaeological layers with mainly Paleolithic settlements were excavated (Matskevyj, 2005).

The Pleistocene fossils assemblage includes remnants of mammoth, four woolly rhinoceroses, insects, vertebrates and plants (Bayger et al., 1914; Stach, 1930). The fossils are perfectly preserved due to combined effect of oil and brine (Kotarba, 2002; Kotarba et al., 2005, 2009; Kubiak, 2001).

The Quaternary sediments are underlain by the Miocene, salt-bearing Vorotyshcha Beds (Korin, 2005). Within Quaternary deposits, close to the tectonic zones, a large number of microcraters of mud volcanoes is located, 2-5 metres distant from each other. The craters are filled with mud saturated with oil, brine and natural gas (Fig. 2). The first volcano has appeared in 1977, after the earthquake in the Vrancea Mts. in Romania. Initially, single cone had four craters of diameters from 0.1 to $0.5 \mathrm{~m}$. Recently, this cone is nearly $1 \mathrm{~m}$ high and has 8 active and 10-20 inactive craters and microcraters. After the earthquakes in Italy, in 1979, second, small mud volcano has appeared some $60 \mathrm{~m}$ east from the first one. Then, in 1981, after the earthquakes in Iran the third mud volcano formed, followed by three others.

In the clays of the of main mud volcano crystals of sphalerite, pyrite, arsenopyrite, gypsum and other minerals were found. In the study area over 300 permanent and periodical springs of mineral waters and brines, and a lot of oil and gas

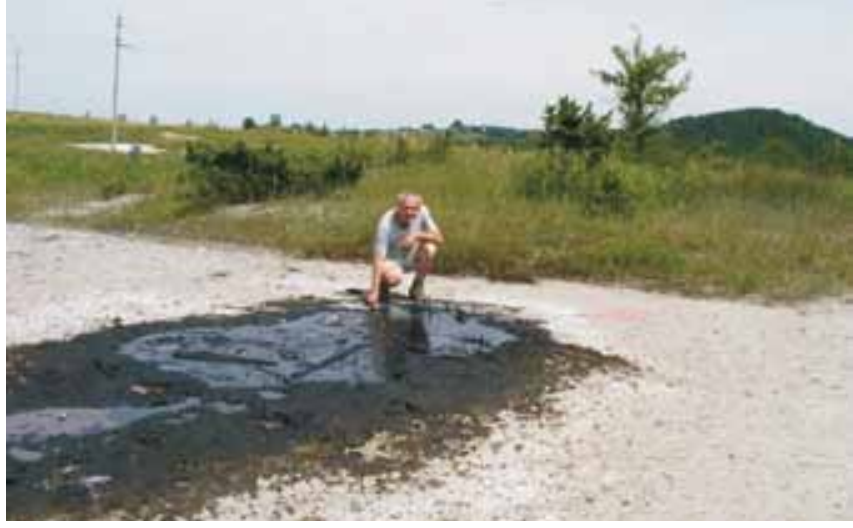

Fig. 2. The crater of mud volcano in Starunia. Photo by W. Barabasz - Krater wulkanu błotnego w Staruni. Fot. W. Barabasz

seeps (Fig. 3) occur. Moreover, the area shows increased seismicity and is still tectonically active, as documented by significant, although irregular uplift (over $1 \mathrm{~m}$ during the years 1977-84) accompanied by the formation of fractures and dynamic expulsions of clay-brine mixture to the surface. Particularly interesting are fractures and fissures, from 0.5 to $3 \mathrm{~cm}$ wide, which open temporary at the surface and close after 3-10 days. Their origin is related to the earthquakes (Stelmakh, 2005). Fractures are usually linked to microcraters and intensively release methane and higher gaseous hydrocarbons as well as oil and brine.

According to Belous et at. (1985), the Starunia area responded to earthquakes, which occurred in previous years in Romania, Italy and Germany but also as far as in Iran, in the Caucasus Mts. and even in Middle Asia, i.e., at the distance of $3000-6000 \mathrm{~km}$. Therefore, the Starunia area is of exceptional scientific value also for the studies on dynamics of the Earth and for forecasting of earthquakes. It is an unique site, interesting not only for the specialists but also for scholars, tourists, students etc. Starunia can be very attractive also for foreign tourists. The development of the Starunia site requires new investments, particularly in road construction and in tourist infrastructure, which would facilitate organization of the ecological-tourist center under the name "The Park of the Ice Age" (Adamenko et al., 2005b).

\section{Idea of ecological and geological tourist centre in Starunia}

In 1974 multidisciplinary ecological, geochemical, geological and geophysical studies were undertaken by specialists from the Ivano-Frankivsk National Technical University of Oil and Gas (IFNTUNG). The purpose of the research was to determine the concentrations of heavy metals and petroleum in underground and surface waters, atmosphere and soil. The results of geological, geomorphological and structural studies revealed recent high level of endogeodynamic activity, which may result in exogenic hazards. The territory can be used as the geodynamic test-ground for the whole Carpathians.

Scientists from Ivano-Frankivsk and Lviv discovered 12 archaeological sites with at least 17 ancient, mainly Paleolith settlements around the Starunia village (Matskevyj, 2005). 


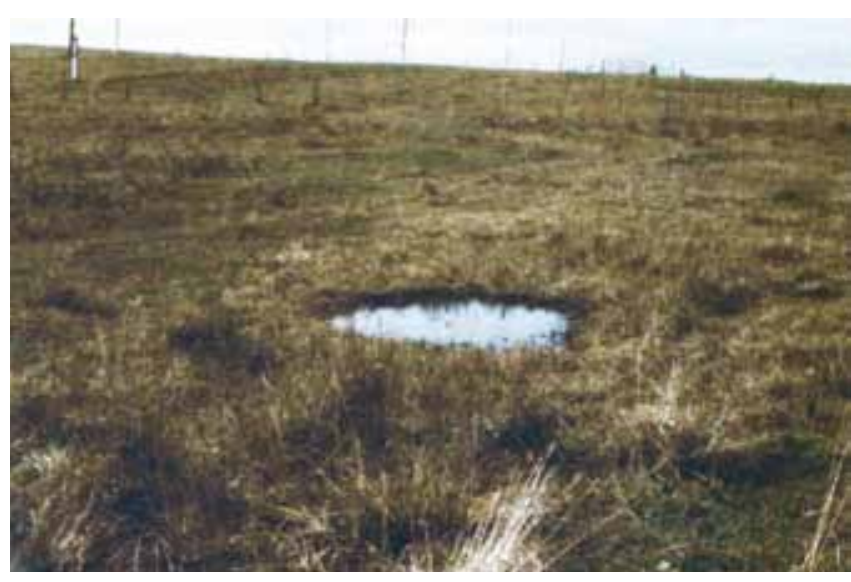

Fig. 3. The oil seep ("oil eye") in Starunia. Photo by O. R. Stelmakh - Powierzchniowy wypływ ropy naftowej (,oczko ropne”) w Staruni. Fot. O. R. Stelmach

Specialists expect further discoveries of ozokerite accumulations as a result of future drillings and, consequently, further findings of fossil animals, and, maybe, also fossil men. Thanks to the efforts of scientists from the Ivano-Frankivsk National Technical University of Oil and Gas the abiotic nature (geological) monument has been established in Starunia by the state authorities. Taking into account an unique value of Starunia area as a geodynamic test-ground for earthquake prediction, as a potential source of Pleistocene fossil flora, fauna and humans, and as ozokerite, oil and gas deposits, a joint research has been organized in the years 2004-2005 by scientists from the AGH University of Science and Technology in Kraków, Poland and the Ivano -Frankivsk National Technical University of Oil and Gas (Kotarba, ed., 2005). The new research was run in the years $2006-$ 2009 (Kotarba, ed., 2009). These studies aimed to extend the knowledge on the Starunia paleontological site, which will result in its better promotion as an object of international value and will attract tourists from all over the world.

The crucial factor in development of the Starunia site as a tourist attraction is fund raising. It is necessary to find investors who would be ready to provide financial resources for the future international ecological and geological tourist centre named "The Park of the Ice Age". The three-stage development plan is presented below:

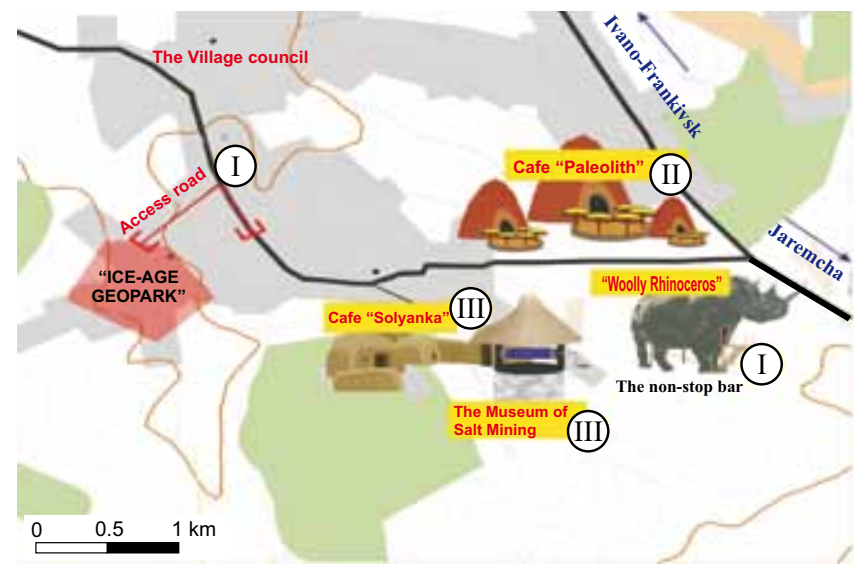

Fig. 4. The tourist objects on the way to "The Park of the Ice Age". Authors: O. M. Adamenko \& D. O. Zorin • Obiekty turystyczne przy drodze do „Parku epoki lodowej”. Autorzy: O. M. Adamenko i D. O. Zorin
1. The first stage of investment will be the opening of non-stop bar located at the crossing of Ivano-Frankivsk-JaremchaKosiv road with local road to Starunia village (Fig. 4). The unusual architecture and name (e.g. "Woolly Rhinoceros") together with special menu should attract tourists and encourage them to stop there and then turn to Starunia village. The local, access road leading to the "Park of the Ice Age" will be upgraded to international standard. Funds will be provided by state authorities from the "Program of tourism development in Ivano-Frankivsk region". In the vicinity of the park private investors will be allowed to built cottages for agro-tourism with a parking lot (Fig. 5). Also the tourist information center and exhibition of full-scale models of woolly rhinoceros, mammoth and other Pleistocene fauna representatives as well as Paleolithic human settlement and artefacts.

2. The second stage of site development will start when the investments of the first stage will make profit. The plan includes construction of café-motel named "Paleolith" of interesting architecture stylized as ancient humans huts (Fig. 4), further construction of agro-touristic cottages (Fig. 6), construction of restaurant and exhibition building where mineralogical samples will be displayed together with models of oil and gas wells and ozokerite shafts, and construction of scientific geodynamic laboratory.

3. The third stage will embrace the construction of the "Solyanka" café and building for the museum of salt mining in the Fore-Carpathian region (Fig. 5), therapeutic brine pool, small wind power plant as well as gondola lift leading to the mountains where tourists will be able to recognize deep forests full of mushrooms, berries or to walk along specially prepared trails. Moreover, the construction of sanatorium "The Carpathian Mud Volcano" is planned.

\section{Conclusions}

The concept of geotourism recently developed in the all World and especially in Europe (www.worldgeopark.com) can be readily applied also in Ukraine where numerous sites can be attractive for domestic and foreign tourists, e.g. the Starunia area, Yavoriv native sulphur open-pit mine recently closed and remediated into a water reservoir (12 square kilometres, depth about 100 metres - deepest in Ukraine) and the Dnistr River canyon.

The presented development plan demonstrates that the Starunia ecological-tourist center "The Park of the Ice Age" with scientific geodynamic laboratory can be completed in 3 years and can make profit for the investors. Simultaneously, the center will provide tourist attractions and will be also the health resort, creating new jobs for local community.

Ukrainian National Geological Monument "Starunia" is a unique protected area in the Ukraine. It gathers a large number of geological peculiarities: (i) complicated geological structure of basement rocks (flysch), (ii) variety of Neogene (molasse) and Quaternary rocks, (iii) six oil deposits (in radius of $20 \mathrm{kms}$ ), (iv) multilayered ozokerite deposit hosted at shallow depth within the Miocene salt-bearing Vorotyshcha Beds, (v) springs of mineral waters and brines, (vi) expulsions 
of natural gas and oil in mud volcanoes and seeps, (vii) permanent, strong neotectonic activity, (viii) place of discovery of fossil Pleistocene fauna and flora, particularly perfectly preserved carcasses of woolly rhinoceroses and mammoth, (ix) archaeological sites since the Paleolith, (x) breathtaking scenic views of the Gorgany Mts. - one of the Eastern Carpathian ridges.

All these valours make Starunia the excellent site for scientific studies and for tourism (geotourism), including the organization of the ecological and geological tourist centre, where knowledge on the latest geological evolution of the Eastern Carpathians, on the Ice-Age fauna and flora, and on human history since the Paleolith would be spreaded among the public, particularly among young generation. Such a unique site must not be left unawared and undeveloped. $\square$

Fig. 5. Design of the ecotourist center "The Park of the Ice Age". Authors: O. M. Adamenko \& D. O. Zorin • Projekt centrum ekologiczno-turystycznego „Park epoki lodowej”. Autorzy: O. M. Adamenko i D. O. Zorin

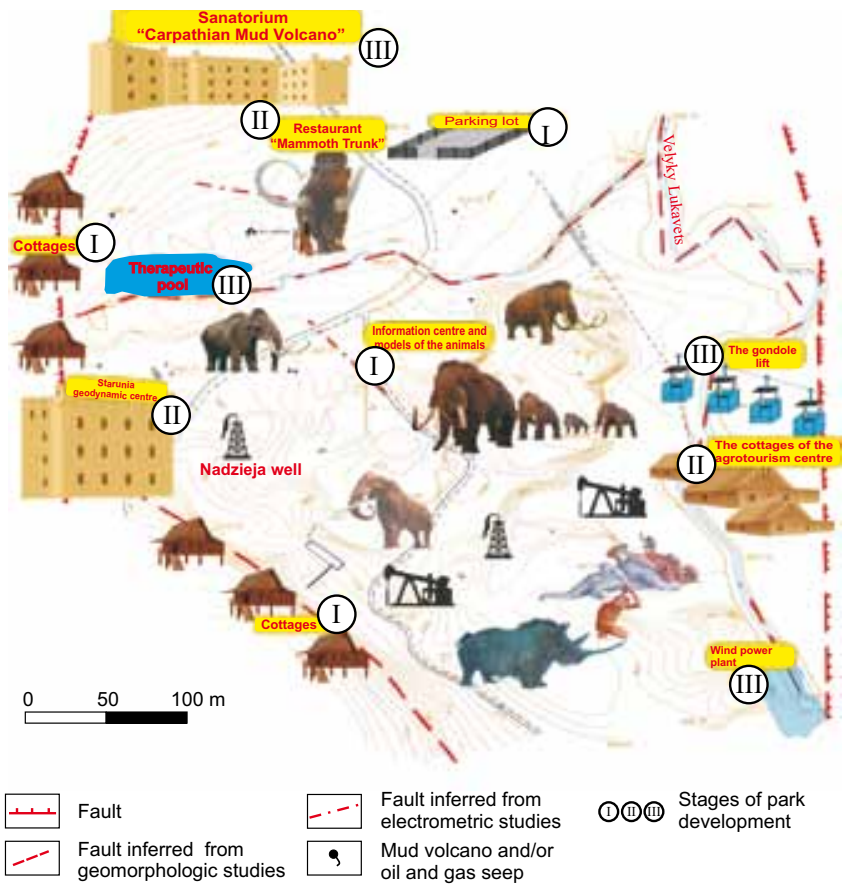

\section{Streszczenie \\ Ekologiczne i geologiczne centrum turystyczne w Staruni (Przedgórze Karpat, Ukraina)}

\section{Oleg M. Adamenko, Orest R. Stelmakh, Denis O. Zorin \& Katya O. Radlovska}

Starunia jest wsią położoną na Przedgórzu Karpat, w powiecie bohorodczańskim niedaleko Ivano-Frankivska (poprzednio Stanisławów, Stanislaw). Znajduje się tu złoże ozokerytu z niewielką ilością ropy naftowej i gazu ziemnego, któremu towarzyszą wulkany błotne i wycieki powierzchniowe ropy naftowej i gazu ziemnego. Stosunkowo niewielki obszar nieczynnej kopalni ozokerytu, na którym utworzono Ukraiński Narodowy Rezerwat Geologiczny obejmuje około 60 hektarów. Rezerwat ten położony jest na wschodnim brzegu doliny rzeki Wielki Łukawiec (Fig. 1). Znajduje się w nim wiele odsłonięć oraz dwie terasy na wysokości 1 i 2,5 m powyżej koryta rzeki. W Staruni złoże ozokerytu było eksploatowane w latach 1868-1960. W roku 1907 w jednym z szybów tej kopalni odkryto szczątki nosorożca włochatego i mamuta. W roku 1929, w specjalnie wykopanym szybie przez Polską Akademię Umiejętności, dodatkowo znaleziono jeszcze trzy nosorożce włochate, w tym jeden prawie kompletnie zachowany unikatowy w skali światowej okaz tego wymarłego gatunku. Ponadto w Staruni w latach 70-tych XX wieku utworzyły się wulkany błotne związane $\mathrm{z}$ aktywnością sejsmiczną. W pobliżu Staruni znaleziono również szczątki osad paleolitycznych, związane z ludźmi, którzy mogli zamieszkiwać ten teren równocześnie z olbrzymimi ssakami.

W podłożu osadów czwartorzędowych zalegają mioceńskie solonośne warstwy worotyszczańskie. W obrębie osadów czwartorzędowych, w pobliżu stref tektonicznych występują liczne mikrokratery wulkanów błotnych. Kratery wypełnio- ne są mułem nasyconym ropą, solanką i gazem ziemnym (Fig. 2). Pierwszy wulkan powstał w roku 1977, po trzęsieniu ziemi w górach Vrancea (Karpaty Mołdawsko-Multańskie, Rumunia). Początkowo, pojedynczy stożek miał cztery kratery o średnicy od 0,1 do $0,5 \mathrm{~m}$, a współcześnie ma on wysokość około $1 \mathrm{~m}$ oraz 8 aktywnych i 10-20 nieczynnych kraterów. Po trzęsieniu ziemi we Włoszech w roku 1979, powstał drugi wulkan błotny około $60 \mathrm{~m}$ na wschód od pierwszego. W roku 1981, po trzęsieniu ziemi w Iranie utworzył się trzeci, a następnie trzy kolejne.

W iłach głównego wulkanu błotnego znaleziono kryształy sfalerytu, pirytu, arsenopirytu, gipsu i innych minerałów. W rejonie Staruni występuje ponad 300 stałych lub okresowych źródeł wód mineralnych lub solanki, a także duże ilości powierzchniowych wycieków ropy i gazu (Fig. 3).

Ukraiński Narodowy Rezerwat Geologiczny „Starunia” jest unikatowym obszarem chronionym na Ukrainie. Zawarte sa w nim liczne osobliwości geologiczne: (I) skomplikowana budowa strukturalna skał podłoże (flisz), (II) zmienność utworów neogeńskich (molasa) i czwartorzędowych, (III) wielohoryzontowe złoże ozokerytu w obrębie mioceńskich solonośnych warstw worotyszczańskich, (IV) sześć złóż ropy naftowej (w promieniu $20 \mathrm{~km}$ ), (V) źródła wody mineralnej i solanki, (VI) wyrzuty ropy i gazu ziemnego w wulkanach błotnych i wyciekach powierzniowych, (VII) stała i silna aktywność neotektoniczna, (VIII) stanowisko paleontologiczne fauny i flory plejstoceńskiej, w tym dobrze zachowanych okazów nosorożców włochatych i mamuta, (IX) paleolityczne stanowiska archeologiczne oraz $(\mathrm{X})$ położenie w przepięknej scenerii Gorganów, pasma Karpat Wschodnich. Czynniki te spowodowały, że Starunia jest wyjątkową w skali światowej atrakcją geoturystyczną, co z kolei pozwoliło na stworzenie planu ekologicznego i geologicznego centrum turystycznego „Park epoki lodowej”. Plan przewiduje trzy etapy rozwoju. W pierwszym, zaplanowano budowę baru non-stop o niezwykłej architekturze i nazwie („Nosorożec włochaty”) na skrzyżowaniu szosy 
Iwano-Frankiwsk - Jaremcza Kosów z lokalną drogą do Staruni oraz drogę dojazdową do planowanego parku (Fig. 4). W okolicy parku powinny zostać zbudowane prywatne gospodarstwa agroturystyczne oraz duży parking (Fig. 5). W parku zostanie utworzone centrum informacyjne $\mathrm{z}$ wystawą pełnowymiarowych modeli nosorożców włochatych, mamuta i innych reprezentantów fauny plejstoceńskiej oraz paleolitycznej osady ludzkiej i przedmioty kultury materialnej. W drugim etapie plan przewiduje wybudowanie zajazdu pod nazwą „Paleolit" o interesującej architekturze stylizowanej na chaty (szałasy) paleolitycznych plemion (Fig. 4), rozbudowę gospodarstw agroturystycznych (Fig. 5), restauracji i budynku wy- stawowego okazów mineralogicznych i petrograficznych oraz modelami wiertni naftowych oraz budynku instytutu naukowego badań dynamiki Ziemi. W etapie trzecim przyjęto zbudowanie kawiarni „Solanka” i budynku muzeum kopalnictwa solnego Przedgórza Karpat, a także kolejkę linową na jedno z otaczających wzgórz, np. górę Bzowacz (Fig. 4, 5), terapeutycznego basenu solankowego, niewielką elektrownię wiatrową. Ponadto zaplanowano budowę sanatorium pod nazwą „Karpacki wulkan błotny”. Centrum to będzie ważnym elementem planowanej transgranicznej trasy geoturystycznej od Staruni po Kraków o nazwie „Szlak wielkich wymarłych ssaków, wosku ziemnego, ropy naftowej i soli”.

\section{References (Literatura)}

Adamenko, O.M., Stelmach, O.R., Zinchuk, M.S. \& Kotarba, M.J., 2005a. History of petroleum exploration in the Starunia area, fore-Carpathian region, Ukraine. In: Kotarba M.J. (ed.) - Polish and Ukrainian geological studies (2004-2005) at Starunia - the area of discoveries of woolly rhinoceroses. Polish Geological Institute and Society of Research on Environmental Changes "Geosphere”, Warszawa-Kraków: 53-60.

Adamenko, O.M., Krizhanivskiy, E.I., Vekeryk, V.I., Stelmach, O.P., Mischenko, L.V., Zorina, N.O., Zorin, D.O. \& Ambrozyak, M.V., 2005b. A concept of an international "Ice-Age Geopark" as an ecological-tourist center in Starunia former ozokerite mine, fore-Carpathian region, Ukraine. In: Kotarba M.J. (ed.) - Polish and Ukrainian geological studies (2004-2005) at Starunia - the area of discoveries of woolly rhinoceroses. Polish Geological Institute and Society of Research on Environmenta Changes "Geosphere", Warszawa-Kraków: 205-209.

Alexandrowicz, S.W., 2004. Starunia and the Quaternary research in the tradition and initiatives of the Polish Academy of Arts and Sciences. Studia i materiały do dziejów Polskiej Akademii Umiejętności. Polish Academy of Arts and Sciences, Kraków, 3: 261 pp. (In Polish, English summary)

Alexandrowicz, S.W., 2005. The history of "Starunia" - a palaeontologic site and old ozokerite mine. In: Kotarba M.J. (ed.) - Polish and Ukrainian geological studies (2004-2005) at Starunia - the area of discoveries of woolly rhinoceroses. Polish Geological Institute and Society of Research on Environmental Changes "Geosphere”, Warszawa-Kraków: 21-36.

Bayger, J.A., Hoyer, H., Kiernik, E., Kulczyński, W., Łomnicki, M., Łomnicki, J., Mierzejewski, W., Niezabitowski, E., Raciborski, M., Szafer, W. \& Schille, F., 1914. Wykopaliska Staruńskie. Muzeum im. Dzieduszyckich we Lwowie, 15: 386 pp. (In Polish only)

Belous, N.H. \& Klyarovskiy, V.M., 1987. Marvel-Starunia (Chudo-Starunia) In: Geologicheskiye pamyatniki Ukrainy. Kyiv, Naukova Dumka: 48-49. (In Russian only)

Belous, N.H., Klyarovskiy, V.M., Starostin, V.A., Bulmasov, V.A., Pluznikova, V.L., Fedoriv, N.M. \& Kolencenko, V.V., 1985. Vyvchennya novitnyoyi tektoniky pivdenno-skhidnoyi chastyny Karpat u zv'yazku z seysmichnoyu aktyvnistyu. Scientific report of the Ivano-Frankivsk Institute of Oil and Gas. Ivano-Frankivsk, 194 pp. (Unpublished report, in Ukrainian only)

Chornobay, Y.M. \& Drygant, D.M., 2009. The Starunia collections in the Natural History Museum of the National Academy of Sciences of Ukraine in Lviv. Geoturystyka, This volume.

Korin, S.S., 2005. Miocene salt-bearing Vorotyshcha Beds in the Starunia area, fore-Carpathian region, Ukraine. In: Kotarba M.J. (ed.) - Polish and Ukrainian geological studies (2004-2005) at Starunia - the area of discoveries of woolly rhinoceroses. Polish Geological Institute and Society of Research on Environmental Changes "Geosphere", Warszawa-Kraków: 79-86.

Kotarba, M.J., 2002. Composition and origin of hydrocarbons saturating the remnants of rhinoceros from Starunia, the Ukrainian Carpathians. Przegląd Geologiczny, 50 (6): 531-534. (In Polish, English summary)

Kotarba, M.J. (ed.), 2005. Polish and Ukrainian geological studies (20042005 ) at Starunia - the area of discoveries of woolly rhinoceroses. Polish Geological Institute and Society of Research on Environmental Changes "Geosphere", Warszawa-Kraków: 218 pp.

Kotarba, M.J., 2009. The Starunia palaeontological site and idea of Ukrainian-Polish trans-border geoturist trail "Traces of large extinct mam- mals, earth wax, oil and salt": from Starunia to Kraków. Geoturystyka, This volume.

Kotarba, M.J. (ed.), 2009. Interdisciplinary studies (2006-2009) at Starunia (Carpathian region, Ukraine) - the area of discoveries of woolly rhinocerouses. Annales Societatis Geologorum Poloniae, 79 (3): 217-480.

Kotarba, M.J., Więcław, D., Koltun, Y.V., Lewan, M.D., Marynowski, L. \& Dudok, I.V., 2005. Organic geochemical study and genetic correlations between source rocks and hydrocarbons from surface seeps and deep accumulations in the Starunia area, fore-Carpathian region, Ukraine. In: Kotarba M.J. (ed.) - Polish and Ukrainian geological studies (20042005) at Starunia - the area of discoveries of woolly rhinoceroses. Polish Geological Institute and Society of Research on Environmental Changes "Geosphere", Warszawa-Kraków: 125-145.

Kotarba, M.J., Więcław, D., Toboła, T., Zych, H., Kowalski, A. \& Ptak, S., 2009. Bitumen and salt contents within the Quaternary sediments at Starunia palaeontologic site (Carpathian region, Ukraine). Annales Societatis Geologorum Poloniae, 79: 447-461.

Kubiak, H., 2001. Unique preservation of a mammoth carcass. Proceedings of the 1st International Congress "The World of Elephants", Roma, 376 pp.

Kubiak, H., 2009. The Starunia collections in the Institute of Systematics and Evolution of Animals, Polish Academy of Sciences in Kraków. Geoturystyka, This volume.

Kubiak, H. \& Drygant, D.M., 2005. The Starunia collections in Lviv and Kraków natural history museums and history of paleontological studies. In: Kotarba, M.J. (ed.), Polish and Ukrainian geological studies (20042005 ) at Starunia - the area of discoveries of woolly rhinoceroses. Polish Geological Institute and Society of Research on Environmental Changes "Geosphere", Warszawa-Kraków: 37-44.

Kuc, T., Różański, K., Goslar, T., Kubiak, H. \& Kotarba, M.J., 2005. Radiocarbon dating of remnants of woolly rhinoceroses and mammoth from Starunia, fore-Carpathian region, Ukraine. In: M.J. Kotarba (ed.) - Polish and Ukrainian geological studies (2004-2005) at Starunia - the area of discoveries of woolly rhinoceroses. Polish Geological Institute and Society of Research on Environmental Changes "Geosphere", Warszawa-Kraków: 195-203.

Matskevyj, L.G., 2005. Archaeological sites in the Starunia area, foreCarpathian region, Ukraine. In: Kotarba M.J. (ed.) - Polish and Ukrainian geological studies (2004-2005) at Starunia - the area of discoveries of woolly rhinoceroses. Polish Geological Institute and Society of Research on Environmental Changes "Geosphere", Warszawa-Kraków: 45-51.

Nowak, J., Panow, E., Tokarski, J., Szafer, W., Stach, J. (eds), 1930. The second woolly rhinoceros (Coelodonta antiquitatis Blum.) from Starunia, Poland. Bulletin International de l'Académie Polonaise des Sciences et des Lettres de Cracovie, Ser. B, Cracovie: 1-49.

Stach, J., 1930. The second rhinoceros from the diluvial strata of Starunia. In: J. Nowak, E. Panow, E., Tokarski, J., Szafer, W., Stach, J. (eds.) - The second woolly rhinoceros (Coelodonta antiquitatis Blum.) from Starunia, Poland. Bulletin International de l'Académie Polonaise des Sciences et des Lettres de Cracovie, Ser. B, Cracovie: 21-47.

Stelmakh, O.R., 2005. Geomorphological and neotectonic features of the Starunia geodynamic test area. In: Kotarba M.J. (ed.) - Polish and Ukrainian geological studies (2004-2005) at Starunia - the area of discoveries of woolly rhinoceroses. Polish Geological Institute and Society of Research on Environmental Changes "Geosphere", WarszawaKraków: 87-93. 